Article

\title{
Comparison of Carbon Dioxide Emissions of the Ordinary Reinforced Concrete Slab and the Voided Slab System During the Construction Phase: A Case Study of a Residential Building in South Korea
}

\author{
Inkwan Paik ${ }^{1}$ and Seunguk $\mathrm{Na}^{2}, *$ (D) \\ 1 Super-Tall Building Global R \& BD Centre, The 2nd Engineering Hall, 152 Jukjeon-ro, Yongin-si, \\ Gyeonggi-do 31116, Korea \\ 2 .Department of Architectural Engineering, College of Architecture, 152 Jukjeon-ro, Yongin-si, \\ Gyeonggi-do 31116, Korea \\ * Correspondence: naseunguk@dankook.ac.kr; Tel.: +82-31-8005-3707
}

Received: 7 June 2019; Accepted: 26 June 2019; Published: 28 June 2019

\begin{abstract}
The construction industry not only consumes a lot of energy but also emits large volumes of carbon dioxide. Most countries have established target reduction values of the carbon dioxide emissions to alleviate environmental burdens and promote sustainable development. The reduction in carbon dioxide emissions in the construction industry has been taking place in various ways as buildings produce large quantities of the carbon dioxide over their construction life cycle. The aim of this study is to assess and compare the carbon dioxide emissions of an ordinary reinforced concrete slab and the voided slab system applied to a case study involving a commercial-residential complex building in South Korea. Process-based life-cycle assessment (LCA) is adopted to compute the carbon dioxide emissions during the construction phase, which includes all processes from material production to the end of construction. The results indicate that the total $\mathrm{CO}_{2}$ emissions are 257,230 and $218,800 \mathrm{~kg} \mathrm{CO}_{2}$ for the ordinary reinforced concrete slab and the voided slab system, respectively. The highest contributor to $\mathrm{CO}_{2}$ reduction is the embodied carbon dioxide emissions of the building materials, which accounts for $34,966 \mathrm{~kg} \mathrm{CO}_{2}$. The second highest contributor is the transportation of the building materials, accounting for $3417 \mathrm{~kg} \mathrm{CO}_{2}$.
\end{abstract}

Keywords: reinforced concrete slab; void slab; residential building; life cycle assessment; process-based; carbon dioxide

\section{Introduction}

It is recognised that the construction industry not only consumes a lot of energy but also emits a large volume of carbon dioxide per [1-9]. According to the report of the Intergovernmental Panel on Climate Change (IPCC), the construction industry accounts for approximately $40 \%$ of global energy consumption and contributes up to $30 \%$ to the total global carbon dioxide emissions [10]. Moreover, carbon dioxide emissions from the construction industry are expected to more than double in the next 20 years unless activities to reduce their quantity are undertaken, owing to rapid urbanisation and limited global housing stock [11]. According to the 1992 Framework Convention on Climate Change, nearly 200 countries have consented to limit the consumption of fossil energy to mitigate anthropogenic climate changes [12]. To alleviate the environmental burdens and promote sustainable development, most countries have established target reduction values for carbon dioxide emissions. The South Korean Government, for example, announced a voluntary target value to reduce domestic greenhouse gases by up to $37 \%$ compared to the business as usual (BAU) scenario [13]. In a similar 
vein, the Chinese government has set up a $20 \%$ greenhouse gas reduction target by 2020. Likewise, the construction industry has been exploring various approaches to achieve the target reduction value of carbon dioxide emissions. Many experts expect that efforts to mitigate carbon dioxide emissions in the construction sector, which produces a significant amount of carbon dioxide emissions, would contribute to a reduction in the total global carbon dioxide emissions [5,6,14-17].

The reduction in carbon dioxide emissions in the construction industry has been taking place in various ways as buildings produce large quantities of carbon dioxide over their entire life cycle, which includes manufacturing building materials, transporting the building materials, construction, operation, and demolition. Research focused on $\mathrm{CO}_{2}$ emissions during the entire life cycle of a building revealed that the construction, operation, and demolition stages account for approximately $13 \%, 85 \%$, and $2 \%$ of $\mathrm{CO}_{2}$ emissions, respectively [7,18-21]. Studies on reducing carbon dioxide emissions in the construction industry have focused on the operational stages rather than other phases, as the life cycle of buildings and facilities is relatively long and accounts for a relatively large proportion of carbon dioxide emissions [20-23]. Several studies have suggested numerous technologies, strategies, and policies to lower the carbon dioxide emissions in the operating stage of buildings [15-18,24-26]. In particular, with the increased application of advanced energy-efficient equipment in buildings, the $\mathrm{CO}_{2}$ produced from the operational stage of buildings has been reduced [24-27]. Furthermore, studies have focused more on reducing carbon dioxide emissions from the operation stage because the lifespan of a building is 50 years or more, which is relatively longer than those of other products. On the other hand, there has been little interest in the carbon dioxide emitted during the construction phase as the amount of carbon dioxide in this stage is relatively smaller than that during the operation stage of a building. Although the amount of carbon dioxide emissions from the construction phase are small, the overall impact of operational carbon dioxide is large [23].

Moreover, several studies have dealt with the impact and significance of the construction phase regarding carbon dioxide emissions $[7,8,15-17,19,25,28,29]$ In particular, most studies have concluded that cutting down the carbon dioxide emissions released by construction materials would be one of the most effective approaches [17,29-31]. González and Navarro [16] found that the selection of low environmental impact materials would reduce carbon dioxide emissions by up to $28 \%$ at the construction site. Cho and Chae [32] suggested methods that use recycled materials or industrial by-products and shortening of the manufacturing process of the construction materials to lower material utilisation during the construction phase. Likewise, replacing high-strength materials such as high-strength rebars and concrete would be one of the effective methods for reducing carbon dioxide emissions. For example, Tae et al. [33] indicate that application of high-strength reinforced concrete would result in a lowering of rebars in reinforced concrete structures as well as extend the life span of buildings. In addition, $\mathrm{Cho}$ and $\mathrm{Na}$ [34] show that replacing the high-strength reinforcing bars in different structural systems would be advantageous to reducing the emissions of carbon dioxide. Alternatively, some of the research suggests that design optimizations with different structural systems would be beneficial to the construction industry with regards to environmental impact. Xing et al. [28] conducted a comparative study which indicated the differences in the life cycle energy consumption and carbon dioxide emissions of steel and reinforced concrete structures. In this study, they demonstrated that steel structured buildings are more environmentally friendly as they emit half of the $\mathrm{CO}_{2}$ per square meter emitted by a reinforced concrete building. In other words, the construction materials and structural system of buildings could be crucial factors determining the emissions of the carbon dioxide during the construction phase.

The voided slab system or hollow core slab system is a hybrid structural system incorporating concrete with void formers to reduce the amount of construction materials. Structurally, the voided slab system is an effective method for extending the span of a building or structure as it reduces the weight of concrete. Several researchers have maintained that the voided slab system would be advantageous not only in terms of structural and economic aspects but also because of its environmental friendliness [35-37]. From the structural design perspective, there are several studies that have examined 
and confirmed the stability and reliability of the voided slab system. Lee et al. [38], for instance, verified the performance of the TVS, which applies lightweight balls to the concrete slab in two-way voided slab-to-column connections. According to Chung et al. [39], the flexural capacities of the two-way voided slab system that is associated with donut-type void formers in the slab are similar to those of conventional reinforced concrete slabs. Moreover, the voided slab system has been adopted gradually in apartment housing in South Korea as an alternative to reduce interlayer noise complaints issues. It was reported that the Seoul Housing and Communities Corporation (SH Corporation), and the Land and Housing Corporation (LH Corporation Korea) have applied the voided slab system to newly built apartment housing as a countermeasure to reduce interlayer noise. Although there have been several studies dealing with the structural performance of the voided slab system, studies on the environmental performance and impact of the voided slab system are limited. Based on previous studies, it is considered that the voided slab system has a dual aspect to maximise the structural performance of a structure and to minimise its environmental impacts.

The purpose of this study was, therefore, to assess and compare the carbon dioxide emissions of an ordinary reinforced concrete slab and the voided slab system applied to a case study involving a commercial-residential complex building in South Korea. In this study, process-based life-cycle assessment (LCA) was adopted to compute the carbon dioxide emissions during the construction phase, which embraces all the processes from materials production to the end of construction (i.e. cradle to pre-operation). The comparison was conducted for the following five stages: building materials before transporting them to the construction site; transporting the building materials to the site; fuel consumptions from the construction equipment; usage of electricity at the site; and transporting the construction waste. The analysed data of this research is further discussed to illustrate the environmental impacts of the ordinary reinforced concrete slab and the voided slab system during the construction phase.

\section{Research Method}

\subsection{Overview of the $\mathrm{CO}_{2}$ Calculation Method}

There are various quantification tools for assessing the environmental impacts of buildings. The methods for quantification and evaluation adopted in previous studies can be categorized into process-based and economic input-output analyses [40-44]. The process-based analysis investigates relevant data from manufacturing to demolition of a product and determine the energy consumption and carbon dioxide emissions from the collected data. This approach is a bottom-up method that complies with ISO 14044 [45] and ISO 21930 [46] for assessing the environmental impacts of products and services based on the production processes. In this method, the environmental impacts and carbon dioxide emissions would be measured by the amount of materials produced and the energy consumed during the production process. For example, Gustavsson and Sathre [47] compared the energy consumption and carbon dioxide emissions of building materials with a focus on wood and concrete by adopting the process-based analysis. When the life cycle of a building is considered to be in compliance with the process-based approach, it is divided into the stages of production, transportation, construction, operation, and demolition. Yan et al. [16] conducted a case study to evaluate the emissions of greenhouse gases in a building construction phase considering the five relevant stages. Similarly, Lee et al. [8] analysed the carbon dioxide emissions in an apartment housing project, which is one of the most popular dwelling types in South Korea. In addition, Dong et al. [25] conducted a comparative study that evaluated the $\mathrm{CO}_{2}$ emissions of precast and cast-in-situ concrete methods by applying the process-based approach. For the process-based perspective, the assessment of carbon dioxide emissions would vary depending on how the assessor would establish the system boundary of the targeted products and services.

The economic input-output analysis is also applied to evaluate the carbon dioxide emissions of products and services. This approach is a top-down method which considers not only direct 
environmental impacts but also indirect impacts of the targeted products or services. The data in economic input-output analysis are normally derived from statistical or census data related to manufacturing a product or delivering a service. In general, it is practical to predict the direct and indirect industrial impacts of products or services on the national economy even though it is time-consuming and expensive to collect all the relevant and available data. Moreover, one of the features of the economic input-output analysis is that enhanced accuracy of the computed results is achieved when the quantity and scope of the data are secured. The application of the input-output analysis in the construction industry is frequently observed in studies conducted in the USA and Japan because the collection of data takes place in more than 400 sectors related to this industry. For example, Suzuki and Oka [48] and Hong et al. [7] carried out research to calculate the carbon dioxide emissions during the construction stage by performing an economic input-output analysis. Likewise, Cho and $\mathrm{Na}$ [34] assessed the variation in $\mathrm{CO}_{2}$ emissions from three different structural types buildings replaced ordinary strength rebars with high-strength reinforcement by adopting an economic input-output analysis. Various studies applying the input-output analysis to evaluate the $\mathrm{CO}_{2}$ emissions during the construction phase have ignored the stages related to transporting materials and waste (e.g. transportation of materials and waste).

In this study, a process-based analysis is used to assess and compare the carbon dioxide emissions from two different slab systems during the construction phase. The construction phase of both slab systems is bounded from the material production to pre-operation stages. It is divided into four stages, which are manufacturing of building materials, transportation of the building materials from the manufacturing location to the construction site, construction, and disposal of the construction waste (See Figure 1).

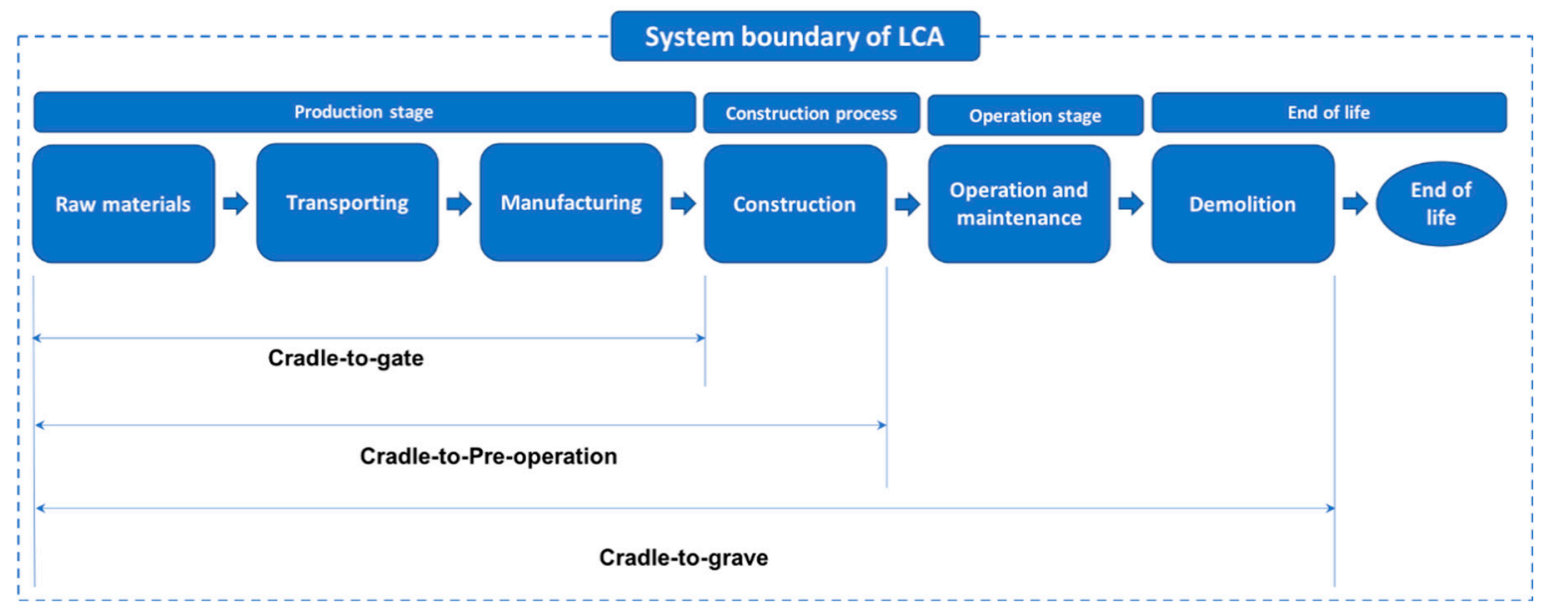

Figure 1. System boundary of the study (Source: own elaboration).

To calculate the emission of carbon dioxide, the four stages of the construction phase are divided into five parts:

(1) Embodied carbon dioxide emissions of building materials before the materials are transported to the construction site;

(2) Carbon dioxide emissions from transporting the building materials to the construction site, which are the result of fuel consumption during the transportation process;

(3) Carbon dioxide emissions from fuel consumption due to operation of equipment and machinery on site;

(4) Carbon dioxide emissions from electricity usage at the construction site;

(5) Carbon dioxide emissions from fuel consumption due to transporting the construction waste. 
The evaluated case of this study is a commercial-residential complex building located in Seoul, South Korea, whose construction started in 2012 and was completed in 2014. The building's structural system was designed in accordance with ACI 318-05 [49] and ASCE/SEI 7-10 [50] and the basic attributes of the building are shown in Table 1. In the early stage of the design, the structural system of the slab was designed such that it would be an ordinary reinforced concrete slab. During the value analysis stage prior to construction documentation, the voided slab system was proposed as an alternative system as it has a remarkable performance against noise insulation as well as the possibility of space variations with increased span. Additionally, because the void formers are easier to install than conventional hollow core slab systems, the void slab system was adopted in this study.

Table 1. The structural attributes of the building.

\begin{tabular}{cc}
\hline Design guidance & $\begin{array}{c}\text { American Concrete Institute (ACI 318-05, Building code requirement for } \\
\text { reinforced concrete [49]) }\end{array}$ \\
$\begin{array}{c}\text { American Society of Civil Engineers (ASCE/SEI 7-10, Minimum design } \\
\text { loads and associated criteria for buildings and other structures [50]) }\end{array}$ \\
\hline $\begin{array}{c}\text { Compressive strength of the } \\
\text { concrete }\end{array}$ & $f_{c k}=24 \mathrm{MPa}$ \\
\hline Tensile strength of the rebars & $f_{y}=400 \mathrm{MPa}$ \\
\hline Dead load & $7.94 \mathrm{kN} / \mathrm{m}^{2}$ \\
\hline Live load & $4.00 \mathrm{kN} / \mathrm{m}^{2}$ \\
\hline
\end{tabular}

\subsection{Calculation Method for Carbon Dioxide Emissions of Building Materials}

The elements for calculating the emissions of carbon dioxide from building materials before transporting the materials to the construction site are the amount of each building material (in $\mathrm{kg}, \mathrm{m}^{3}$, and $\mathrm{m}^{2}$ ) and $\mathrm{CO}_{2}$ emission factors (in $\mathrm{kg} \mathrm{CO}_{2}$-eq / unit) for the building materials. The equation 1 was used to calculate the embodied carbon dioxide emissions of building materials for the ordinary reinforced slab and the voided slab system.

$$
E_{1}=\sum M_{i} \times f_{i}
$$

where $E_{1}$ represents the total embodied carbon dioxide emissions of building materials (in $\mathrm{kg} \mathrm{CO}_{2}$ eq); $M_{i}$ is the amount of the building material $i$; and fi is the $\mathrm{CO}_{2}$ emission factor for the building material $i$ (in $\mathrm{kg} \mathrm{CO}_{2}$-eq / unit). The amounts of building materials for the ordinary reinforced concrete slab and the voided slab system were computed from the bill of quantities and daily construction work reports. The $\mathrm{CO}_{2}$ emission factors for building materials were obtained from the Korean national life-cycle inventory database (KLCI DB) as shown in Table 2 [51].

Table 2. Life-cycle inventory database.

\begin{tabular}{cccc}
\hline Materials & Unit & $\begin{array}{c}\text { Emission Factors } \\
\text { (kg CO } \mathbf{2} \text {-eq/unit) }\end{array}$ & Resource \\
\hline Ready-mixed concrete (25-240-15) & $\mathrm{m}^{3}$ & $4.20 \times 10^{2}$ & $\begin{array}{c}\text { The Korean National } \\
\text { Life-Cycle Inventory Database } \\
\text { (KLCI DB) }\end{array}$ \\
\hline Rebars & $\mathrm{kg}$ & $3.40 \times 10^{1}$ & \\
\hline Forms & $\mathrm{m}^{2}$ & $1.46 \times 10^{2}$ & \\
\hline Expanded polystyrene (EPS) & $\mathrm{kg}$ & $1.87 \times 10^{1}$ \\
\hline Steel decking & $\mathrm{m}^{2}$ & $3.85 \times 10^{1}$ & \\
\hline
\end{tabular}




\subsection{Calculation Method for Transportation of Building Materials}

The main factors needed to calculate the $\mathrm{CO}_{2}$ emission due to transportation of construction materials were the amount of construction materials and the fuel consumed by the transportation methods. Equation (2) shows the calculation formula for $\mathrm{CO}_{2}$ emissions from transporting construction materials to the construction site.

$$
\left.E_{2}=\sum\left(F_{C} \times N_{\text {Trans }}\right) \times f_{\text {trans }} 2\right)=\sum\left[\left(D_{m} / F E_{m}\right) \times\left(M_{m} / C_{\text {Cap }}\right)\right] \times f_{\text {trans }}
$$

where $E_{2}$ represents the total $\mathrm{CO}_{2}$ emissions from transportation of all construction materials (in $\mathrm{kg}$ $\mathrm{CO}_{2} \mathrm{eq}$ ); $F_{c}$ is the amount of fuel consumed in the transportation stage (in $\mathrm{kg} \mathrm{CO}_{2}$ ); $N_{\text {Trans }}$ is the number of vehicles for construction materials; and $f_{\text {trans }}$ represents the $\mathrm{CO}_{2}$ emission factors for the transportation method ( $\mathrm{kg} \mathrm{CO}_{2}-\mathrm{eq} / \mathrm{kg}$ ). The amount of consumed fuel for each transportation method $\left(F_{c}\right)$ was estimated based on the distance between the suppliers' location and the construction site, and the fuel efficiency. In addition, the number of vehicles for transporting the construction materials was determined in consideration of the amount of construction materials and the capacity of the transportation method for each material (see Equation (3)).

$$
E_{2}=\sum\left[\left(D_{m} / F E_{m}\right) \times\left(M_{m} / C_{\text {Cap }}\right)\right] \times f_{\text {trans }}
$$

where $D_{m}$ is the distance from the supplier's location to the construction site; $F E_{m}$ is the fuel efficiency of the transportation method (e.g. the fuel efficiency of a concrete mixer and 4.5-ton lorry); $M_{m}$ is the amount of construction materials (in $\mathrm{m}^{3}$ for ready-mixed concrete, and $\mathrm{kg}$ for reinforcing bars, and steel decking and forms); and $C_{c a p}$ is the capacity of the transportation method. The transportation distance applied in this study was calculated based on the actual distance indicated in the construction work $\log$ as shown in Table 3. In this study, the transportation methods of construction materials were different for each material. For example, the ready-mixed concrete was transported by a concrete mixer, and reinforcing bars and steel decking were delivered by 11.5-ton lorries, and forms and void formers were conveyed by 4.5 -ton lorries.

Table 3. Materials and type of transportation of the construction materials (Source: own elaboration).

\begin{tabular}{ccc}
\hline Materials & Distance (Unit: $\mathbf{k m )}$ & Type of Transportation \\
\hline Ready mixed concrete & 25 & Concrete mixer \\
\hline Reinforcing bars & 380 & Lorry (11.5 ton) \\
\hline Steel decking & 110 & Lorry (11.5 ton) \\
\hline Forms & 30 & Lorry (4.5 ton) \\
\hline Void formers & 40 & Lorry (4.5 ton)
\end{tabular}

\subsection{Calculation Method for Carbon Dioxide Emissions from Fuel Consumption of Construction Equipment Operation}

In this study, we considered that the amount of carbon dioxide emissions given off by the construction equipment was closely related to the quantity of fuel consumed by the construction equipment on site. The amount of fuel consumed by the construction equipment was divided into two types: that consumed during actual operation and that consumed during idling time. When the construction equipment was operated in the construction fields, it was noticed that most of the machinery and equipment on site were turned on but standing by rather than only being turned on when needed for particular operations. For this reason, we considered that it would be reasonable to estimate the amount of fuel consumption from the construction machinery and equipment in two types as mentioned above (i.e. the fuel consumption during operation and idling time). 
Based on this consideration, the total emissions of $\mathrm{CO}_{2}$ from the construction equipment is the sum of $\mathrm{CO}_{2}$ emissions in the operation and idling time. Equation (4) represents the emissions of carbon dioxide in the construction stage from operation of the equipment. The carbon dioxide emissions for $E_{\text {oper }}$ and $E_{\text {idle }}$ were estimated by applying the following formulae, which calculated the amount of consumed fuel for the construction equipment.

$$
E_{3}=E_{\text {oper }}+E_{\text {idle }}=\sum\left(L_{\text {ope }} \times f_{i}\right)+\left(L_{\text {idle }} \times f_{i}\right)
$$

where $E_{3}$ represents the total carbon dioxide emissions during the construction stage resulting from construction equipment usage (in $\mathrm{kg} \mathrm{CO}_{2}$ eq); $E_{\text {oper }}$ are the carbon dioxide emissions released owing to fuel consumption in operation of the construction equipment (in $\mathrm{kg} \mathrm{CO}_{2} \mathrm{eq}$ ); $E_{\text {idle }}$ is the amount of $\mathrm{CO}_{2}$ emitted by the construction equipment during the idling time (in $\mathrm{kg} \mathrm{CO}_{2}$ eq); $L_{\text {ope }}$ is the amount of fuel consumed during operation of the construction equipment; $f_{i}$ is the carbon dioxide emission factor of fuel $i$; and $L_{i d l e}$ is the amount of fuel consumed by the construction equipment in the idling time. The carbon dioxide emissions factors for types of fuel are indicated in Table 4. The fuel consumed during operation of construction equipment and idling time was calculated using Equations (5) and (6).

$$
L_{\text {oper }}=\left(Q / R_{\max }\right) \times F E_{\text {oper }}
$$

where $Q$ is the capacity of concrete that is used by the construction equipment $\left(\mathrm{m}^{3}\right) ; R_{\max }$ is the actual maximum output capacity of the concrete pump car; and $F E_{o p e r}$ is the fuel efficiency of the concrete pump car in the operation time (in $\left.\mathrm{m}^{3} / l\right)$.

$$
L_{\text {idle }}=\left[T_{\text {conc }}-\left(Q / R_{\max }\right)\right] \times F E_{\text {idle }}
$$

where $T_{\text {conc }}$ is the required time for concrete work; and $F E_{\text {idle }}$ is the fuel efficiency of the concrete pump car in the idling time (in $\mathrm{m}^{3} / l$ ). In this study, the required time for concrete work and the fuel consumption in the operation and idling time were adopted from the Korean National Database of the construction material environmental information and the Korean Standard Specification [52]. Furthermore, the amount of fuel consumed by the construction equipment was calculated based on the actual amount, which was determined from the bill of quantities and the construction daily report. Through the application of the actual data from the construction site, enhanced accuracy of the carbon dioxide emissions from the construction equipment and machinery would be expected.

Table 4. The carbon dioxide emissions factors for type of fuel.

\begin{tabular}{cccc}
\hline Type of fuel & Unit & $\begin{array}{c}\text { Emission Factors } \\
\text { (kg CO } \text { 2-eq/unit) }^{- \text {Resource }}\end{array}$ & Rec \\
\hline Diesel & $\mathrm{kg}$ & $6.82 \times 10^{-2}$ & National LCI DB [51] \\
\hline Petrol & $\mathrm{kg}$ & $8.32 \times 10^{-2}$ & National LCI DB [1] \\
\hline
\end{tabular}

\subsection{Calculation Method for Carbon Dioxide Emissions from Electricity Usage at the Construction Site}

The carbon dioxide emissions due to electricity usage at the construction site were calculated by the use of Equation (7).

$$
E_{4}=\sum E_{j} \times f
$$

where $E_{4}$ are the total carbon dioxide emissions from electricity usage at the construction site (in $\mathrm{kg}$ $\mathrm{CO}_{2}$ ); $E_{j}$ is the quantity of electricity purchased from power company $j$ (in $\mathrm{kWh}$ ); and $f$ is the carbon dioxide emission factor for the electricity in South Korea (in $\mathrm{kg} \mathrm{CO}_{2} / \mathrm{kWh}$ ). The carbon dioxide emission factor for the electricity in South Korea is a nation-wide value of $0.4961 \mathrm{~kg} \mathrm{CO}_{2} \mathrm{eq} / \mathrm{kWh}$ because it is provided by only one company that is the Korea Electric Power Corporation. 


\subsection{Calculation Method for Carbon Dioxide Emission from Fuel Consumption Due to Transportation of Construction Waste}

Equation (8) was applied to calculate the carbon dioxide emissions from the fuel combustion that occurred when construction waste was transported from the construction site to the landfill.

$$
E_{5}=\sum\left[\left(D_{w} / F E_{m}\right) \times\left(M_{w} / C_{C a p}\right)\right] \times f
$$

where $\mathrm{E}_{5}$ are the total $\mathrm{CO}_{2}$ emissions from fuel consumption of the transportation method; $D_{w}$ is the distance from the construction site to the waste-processing facilities location; $F E_{m}$ is the fuel efficiency of the transporting method (in this study, the method of the transporting construction waste was 15-ton dump trucks); $M_{w}$ is the amount of the construction waste generated during the construction work (in $\mathrm{m}^{3}$ ); and $C_{\text {cap }}$ is the capacity of the transportation method. The distance between the construction site and the landfill was adopted from the construction log and the distance was $28 \mathrm{~km}$ from the site to the landfill.

\section{Data Analysis}

\subsection{Total $\mathrm{CO}_{2}$ Emissions of the Ordinary Reinforced Concrete Slab and the Voided Slab System}

According to formulas (1)-(8), Total carbon dioxide emissions from the construction phase are shown in Table 5. The total carbon dioxide in the construction phase of the ordinary reinforced concrete slab and the voided slab system are 257,230 and $218,800 \mathrm{~kg} \mathrm{CO}_{2}$, respectively. In both cases, the majority of the carbon dioxide emissions are due to manufacturing the building materials, which accounts for approximately $96 \%$. A reduction of $38,394 \mathrm{~kg} \mathrm{CO}_{2}$ was seen in the voided slab system, which is approximately $14.9 \%$ less than that of the ordinary reinforced concrete slab.

Column 8 in Table 5 indicates the contribution proportion of each emissions source to the total carbon dioxide emission reduction due to the application of the voided slab system over the ordinary reinforced concrete slab. A total of $14.2 \%$ of the carbon dioxide emission reduction are due to the manufacturing of building materials $\left(E_{1}\right) ; 39.1 \%$ of the reductions are due to the energy consumption of transporting the building materials to the construction site $\left(E_{2}\right)$; and $1.2 \%$ and $1.1 \%$ of carbon dioxide emission reduction are from on-site electricity usage $\left(E_{4}\right)$ and the transportation of the construction waste $\left(E_{5}\right)$, respectively. However, a slight increase of $3.2 \%$ was shown in the consumption of fuel from operation of the construction equipment in the voided slab system compared to the ordinary reinforced concrete slab $\left(E_{3}\right)$. This was only observed in the voided slab system, and it would be regarded as having a negative effect on the carbon dioxide emission reduction in the voided slab system.

Table 5. Total $\mathrm{CO}_{2}$ emissions from the construction phase (Source: own elaboration).

\begin{tabular}{cccccccc}
\hline \multirow{2}{*}{ Sources } & \multicolumn{2}{c}{ Ordinary Reinforced Concrete Slab (O) } & \multicolumn{2}{c}{ Voided Slab System (V) } & \multicolumn{2}{c}{ Reduction } & \multicolumn{2}{c}{$\begin{array}{c}\text { Percentage } \\
\text { ([O - V]/O) }\end{array}$} \\
\cline { 2 - 6 } & $\mathbf{C O}_{2}$ & $\%$ & $\mathbf{C O}_{2}$ & $\%$ & $\mathbf{O}-\mathbf{V}$ & $\%$ & \\
\hline$E_{1}$ & 246,082 & 95.6 & 211,116 & 96.5 & 34,966 & 91.1 & 14.2 \\
\hline$E_{2}$ & 8744 & 3.4 & 5327 & 2.4 & 3417 & 8.9 & 39.1 \\
\hline$E_{3}$ & 351 & 0.14 & 363 & 0.17 & -12 & -0.03 & -3.2 \\
\hline$E_{4}$ & 830 & 0.32 & 820 & 0.37 & 10 & 0.03 & 1.2 \\
\hline$E_{5}$ & 1223 & 0.50 & 1174 & 0.54 & 13 & 0.03 & 1.1 \\
\hline Total & 257,230 & 100 & 218,800 & 100 & 38,394 & 100 & 14.9 \\
\hline
\end{tabular}

As shown in Table 5, the manufacturing of the building materials is the dominant source of the carbon dioxide emissions both in the ordinary reinforced slab and the voided slab system which account for $95.5 \%$ and $96.3 \%$, respectively (See Figure 2). The second largest contributor to the carbon 
dioxide emissions is the transportation of the building materials $\left(E_{2}\right)$, accounting for $3.6 \%$ and $1.7 \%$ in the ordinary reinforced concrete slab and the voided slab system, respectively (see Figure 2).

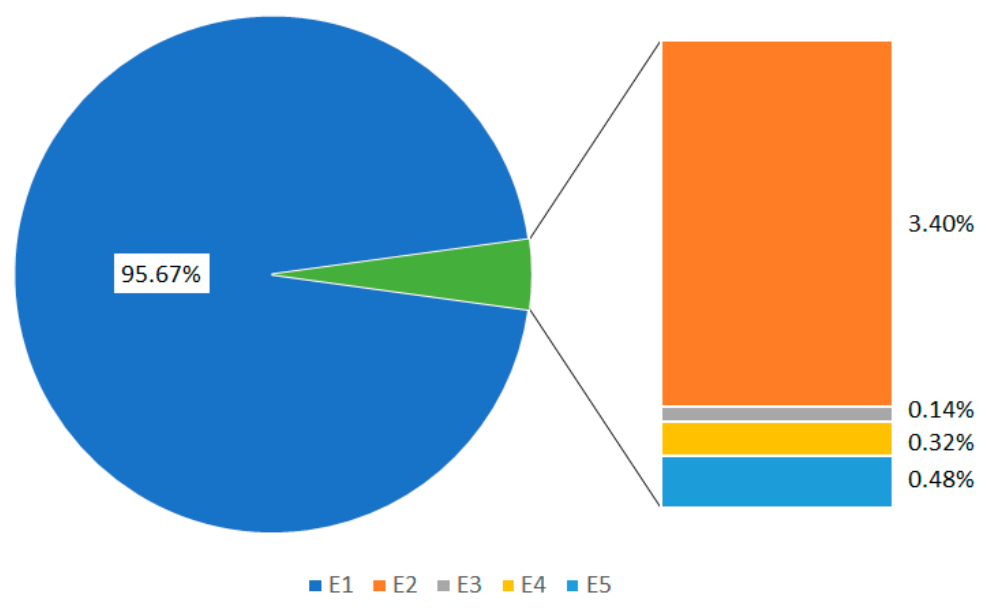

(a) $\mathrm{CO}_{2}$ emissions of the ordinary reinforced concrete slab

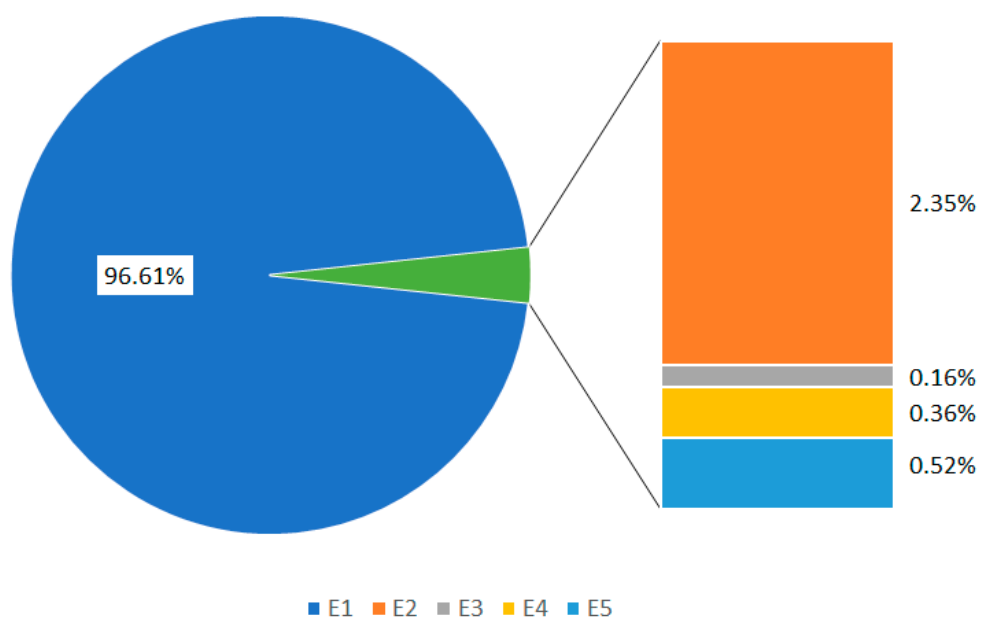

(b) $\mathrm{CO}_{2}$ emissions of the voided slab system

Figure 2. $\mathrm{CO}_{2}$ emissions of the ordinary reinforced concrete slab and the voided slab system (Source: own elaboration).

The analysed data indicate that manufacturing of the building materials contributes the most of carbon dioxide emissions in building construction phases, as indicated in Figure 3. Overall, the voided slab system emits approximately $15 \%$ less carbon dioxide emissions than the ordinary reinforced slab. Thus, when the carbon dioxide emissions of the voided slab system are compared to those of the ordinary reinforced concrete slab, all the elements of the building construction phases emit less carbon dioxide.

\subsection{Carbon Dioxide Emissions of the Building Materials}

As the largest source of total carbon dioxide emissions in both types of slab systems, the emissions of carbon dioxide depend on the types of materials used in each slab system. As for the total carbon dioxide emissions, the voided slab system emits $38,394 \mathrm{~kg} \mathrm{CO}_{2}$ less, which accounts for about $15 \%$ (see Table 5). 


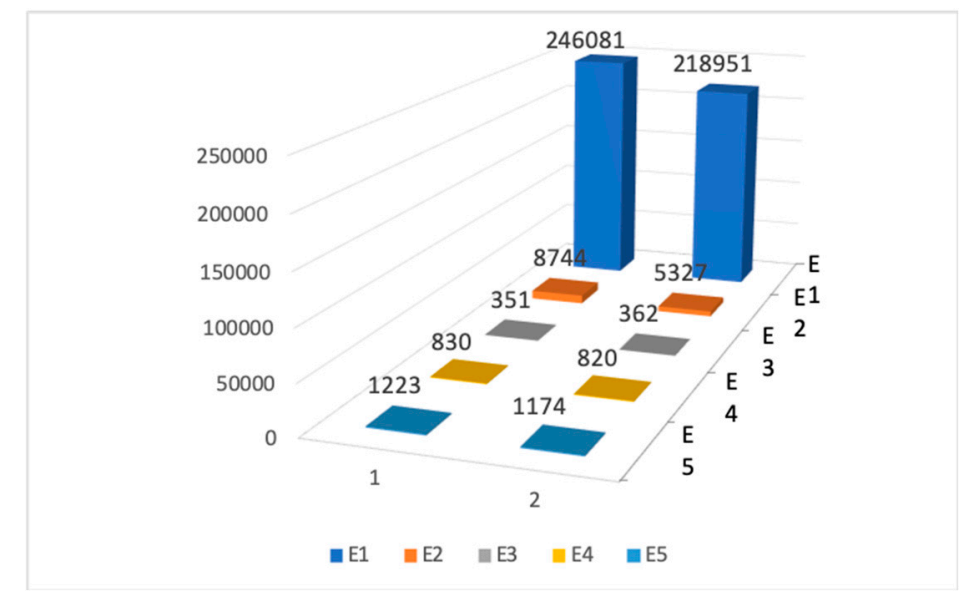

Figure 3. Total carbon dioxide emissions (Unit: $\mathrm{kg} \mathrm{CO}_{2}$ eq) (Source: own elaboration).

As shown in Table 6, concrete in both the ordinary reinforced concrete slab and the voided slab system release 142,426 and $154,135 \mathrm{~kg} \mathrm{CO}_{2}$, respectively. In the voided slab system, the $\mathrm{CO}_{2}$ emissions of concrete contribute more than those of the ordinary reinforced concrete slab (see Figure 4). This result is due to the characteristics of the voided slab system, in which the depth of the voided slab is increased in order for the system to attain the same structural performance as the ordinary reinforced concrete slab. Despite increasing the depth of the voided slab system, the volume of carbon dioxide emissions of concrete in the voided slab system is relatively small because the number of beams and girders are fewer (see Table 6). Such a decrease leads to a lower number of reinforcing bars and steel materials. Thus, the emissions of carbon dioxide increase at a relatively smaller rate than those of other materials in the voided slab system.

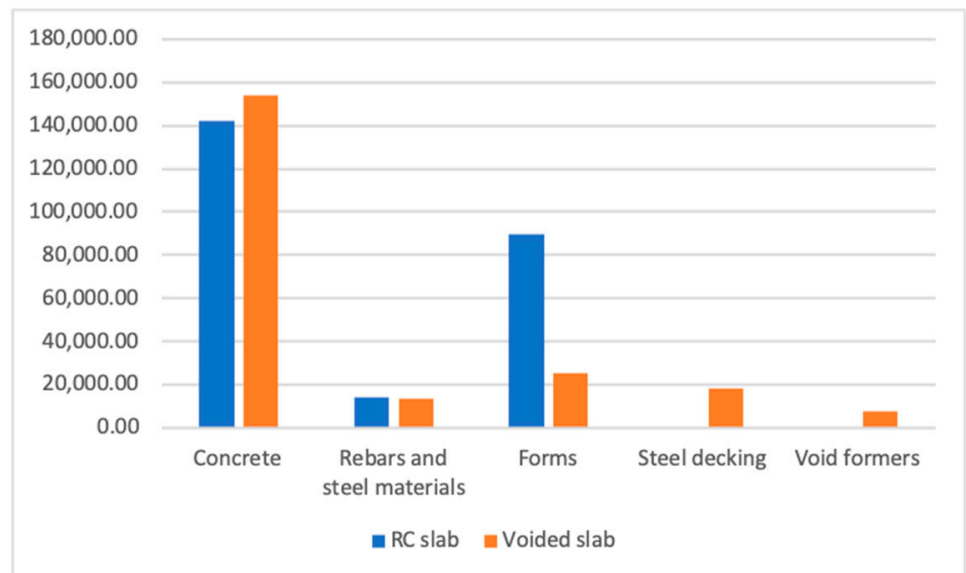

Figure 4. The $\mathrm{CO}_{2}$ emissions of the building materials (Source: own elaboration).

The most distinct reduction in the carbon dioxide emissions in the building materials was due to the forms in the voided slab system. From Table 6, a relatively large amount of forms is required to mould the beams and girders in the ordinary reinforced concrete slab. On the other hand, it would be possible to reduce the beams and girders in the structural members of the voided slab system by increasing the area moment of inertia due to the increased depth of the slab. Thus, this would make it possible to achieve both of the structural reliability and the environmental friendliness by adopting the voided slab system for buildings.

Likewise, removing beams and girders in the voided slab system would also result in a reduction in carbon dioxide emissions. In order to complement the role of forms in the lower of the slabs, the steel decking used in the voided slab system serve not only to form the bottom of the slabs but also as 
an additional structural member. These results indicate that replacing the ordinary reinforced concrete slab with the voided slab system would be beneficial to reducing the carbon dioxide emissions in the building materials.

Table 6. Carbon dioxide emissions of the construction materials (Source: own elaboration).

\begin{tabular}{|c|c|c|c|c|c|c|c|c|}
\hline \multicolumn{2}{|c|}{ Materials - } & \multicolumn{2}{|c|}{$\begin{array}{c}\text { Ordinary Reinforced } \\
\text { Concrete }\end{array}$} & \multicolumn{2}{|c|}{$\begin{array}{l}\text { Voided Slab } \\
\text { System }\end{array}$} & \multicolumn{2}{|c|}{ Reduction } & \multirow[t]{2}{*}{ Sources } \\
\hline & & $\mathrm{kgCO}$ & $\%$ & $\mathrm{~kg} \mathrm{CO}$ & $\%$ & $\mathrm{kgCO}$ & $\%$ & \\
\hline \multirow{3}{*}{ Concrete } & Slab & 61,043 & 24.8 & 92,820 & 43.9 & $-31,777$ & -12.9 & \multirow{12}{*}{$\begin{array}{c}\text { KLCI DB } \\
\text { [51] }\end{array}$} \\
\hline & $\begin{array}{l}\text { Beams and } \\
\text { girders }\end{array}$ & 81,383 & 33.1 & 61,315 & 29.0 & 20,068 & 8.2 & \\
\hline & Sub-total & 142,426 & 57.9 & 154,135 & 72.9 & $-11,709$ & -4.7 & \\
\hline \multirow{3}{*}{$\begin{array}{c}\text { Rebars and } \\
\text { steel materials }\end{array}$} & Slab & 4403 & 1.8 & 6617 & 3.1 & -459 & -0.2 & \\
\hline & $\begin{array}{l}\text { Beams and } \\
\text { girders }\end{array}$ & 9750 & 4.0 & 6929 & 3.3 & 587 & 0.3 & \\
\hline & Sub-total & 13,546 & 5.8 & 13,546 & 6.4 & 125 & 0.1 & \\
\hline \multirow{3}{*}{ Forms } & Slab & 48,110 & 19.6 & 0 & 0 & 48,110 & 19.6 & \\
\hline & $\begin{array}{l}\text { Beams and } \\
\text { girders }\end{array}$ & 41,392 & 16.8 & 25,269 & 12.0 & 16,123 & 6.6 & \\
\hline & Sub-total & 89,502 & 36.4 & 25,269 & 12.0 & 64,233 & 26.2 & \\
\hline \multicolumn{2}{|c|}{ Steel decking } & N.A. & N.A. & 18,165 & 8.6 & $-18,165$ & -7.4 & \\
\hline \multicolumn{2}{|c|}{ Void formers } & N.A. & N.A. & 7,836 & 0 & -0.000008 & 0 & \\
\hline \multicolumn{2}{|c|}{ Total } & 246,082 & 100 & 218,951 & 100 & 27,131 & 12.4 & \\
\hline
\end{tabular}

\subsection{Carbon Dioxide Emissions of Transporting Building Materials}

Carbon dioxide emissions associated with transporting building materials are the second largest contributor to the emissions of carbon dioxide in both slab systems. From Table 5, the carbon dioxide emissions from transporting building materials are 8744 and $5327 \mathrm{~kg} \mathrm{CO}_{2}$ for the ordinary reinforced concrete slab and the voided slab system, respectively. The reduction in transporting building materials is only $8.9 \%$ from total carbon dioxide emissions as can be seen from Table 5 .

As for the transportation of ready-mixed concrete in both slab systems, the $\mathrm{CO}_{2}$ emissions were reduced through the selection of a ready-mixed concrete plant close to the construction site. The standard capacity of the ready-mixed concrete mixers in South Korea is $6.0 \mathrm{~m}^{3}$ and the consumption of the fuel by the mixer trucks was calculated based on the volume of these lorries. Because of the standardised use of the concrete mixer trucks in ready-mixed concrete transportation, the number of trucks required could not be altered. To reduce the consumption of fuel by the mixer trucks and the emissions of the carbon dioxide, the distance between the ready-mixed concrete plant and the construction site $(25 \mathrm{~km})$ was considered as short as possible during the construction planning stage. Reducing the carbon dioxide emissions through allocation of construction site and the manufacturers is similar to the approach used in previous studies which optimize transportation distance between factories and the construction site $[8,16,20]$. In this study, it is confirmed that lowering the transportation distance would be one of the effective approaches to reduce the carbon dioxide emissions during the construction phase.

However, the transportation of void formers in the voided slab system requires quite a large number of lorries even though the weight of the void formers is lower than those of other building materials in this study. The reason for requiring more lorries to transport the void formers is that the height was a more significant factors for conveying the void formers than the weight owing to the road traffic act in South Korea. The height of the lorries for transporting the void formers was $2.35 \mathrm{~m}$ which were the optimal size for conveying the void formers. Since the studied building was constructed in 
the city centre, the 4.5 -ton lorries with the height of $2.35 \mathrm{~m}$ were the best possible option in this project. In addition, as the distances of the expanded polystyrene (EPS) plant, which is the raw material of the void formers, are far greater than those of other materials, emissions of carbon dioxide occurred during the transportation of the void formers.

\subsection{Carbon Dioxide Emissions from Fuel Consumption of Construction Equipment Operation}

The emissions of carbon dioxide from the construction phase were calculated by computing the amount of consumed fuel from the construction equipment and machinery. As indicated in Table 7, the consumed fuel in the construction phase was calculated based on the input amount of machinery and equipment from the daily construction report and log.

Table 7. Consumption of fuel and carbon dioxide emissions (Source: own elaboration).

\begin{tabular}{ccc}
\hline & Ordinary Reinforced Concrete Slab & Voided Slab System \\
\hline Volume of concrete $\left.\mathbf{( m}^{\mathbf{3}}\right)$ & 339.11 & 366.99 \\
\hline Concrete pouring time (hour) & 9.0 & 9.7 \\
\hline Fuel in the active time (1) & 66.69 & 72.17 \\
\hline Fuel in the idling time (1) & 50.78 & 54.57 \\
\hline $\mathrm{CO}_{\mathbf{2}}$ emissions $\left(\mathrm{kg} \mathrm{CO}_{\mathbf{2}}\right)$ & 351 & 363 \\
\hline
\end{tabular}

In this study, the operating time of the construction equipment and machinery was divided into the active and the idling time. The reason for considering the active and idling time of the construction equipment separately is that construction equipment and machinery are left in the idle mode so that it is easier to operate them when needed at the construction site. As the amount of fuel consumed during the idling time is quite large, this study considered the fuel consumed during idling and operation separately. Based on the consumed fuel amount, it is indicated that the carbon dioxide emissions from the construction machinery and equipment operation are 351 and $363 \mathrm{~kg} \mathrm{CO}_{2}$ for the ordinary reinforced concrete slab and the voided slab system, respectively.

As indicated in Table 7, the fuel consumption during the idling time is approximately $42 \%$ and $43 \%$ for the ordinary reinforced concrete slab and the voided slab system, respectively. In addition, $75 \%$ of consumed fuel is consumed during the idling time. In other words, this means that the amount of fuel from the idling time in the equipment and machinery operation is quite large and it should be considered to minimize the emissions of carbon dioxide from the construction machinery and equipment during the construction stage.

\subsection{Carbon Dioxide Emissions from Electricity Usage and Construction Waste Transportation}

The $\mathrm{CO}_{2}$ emissions from electricity usage on site were 830 and $820 \mathrm{~kg} \mathrm{CO}_{2}$ for the ordinary reinforced concrete slab and the voided slab system, respectively (see Table 5). In the case of the voided slab system, void formers and steel decking, which replace the rebars and steel materials, are used to anchor void formers to lower reinforcement in the slabs, were the main factors that reduced electricity usage during the steel materials process stage as well as the carbon dioxide emissions during the construction stage. In addition, the lowering of the rebars and steel materials would make it possible to reduce the generation of construction waste. Thus, replacement of the ordinary reinforced concrete slab with the voided slab system would contribute to a reduction in carbon dioxide emissions from electricity usage and the generation of construction waste on site.

\subsection{Comparison of the Carbon Dioxide Emissions by Structural Members}

The carbon dioxide emissions of the structural members in the ordinary reinforced concrete slab and the voided slab system were significantly different in this study. In the case of the voided slab 
system, the numbers of beams and girders were significantly less than those for the ordinary reinforced concrete slab. As a result of the decrease in the number of beams and girders, it was observed that the forms and reinforcing bars were the main elements reducing the carbon dioxide emissions in the voided slab system (see Figure 5). As seen in Table 7, forms are the significant reduction factor in the voided slab system, resulting in a reduction of approximately $65 \%$.

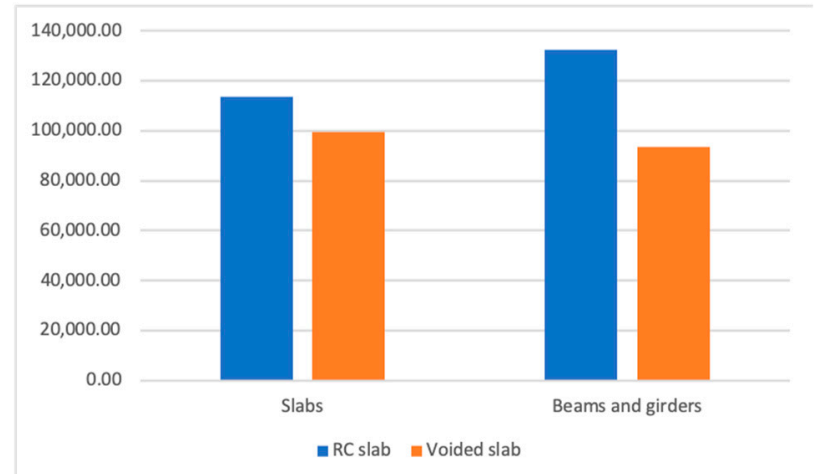

Figure 5. Carbon dioxide emissions of structural members (Source: own elaboration).

\section{Conclusions}

The purpose of this study was to compare the carbon dioxide emissions of the ordinary reinforced concrete slab and the voided slab system during the construction phase, which includes all processes from manufacturing the building materials to the pre-operation stage. The building construction phase emits significant quantities of the carbon dioxide emissions from both slab systems. The voided slab system is an alternative to the ordinary reinforced concrete slab. In this study, five sources of carbon dioxide emissions for the ordinary reinforced concrete slab and the voided slab system are identified for comparing the emissions of $\mathrm{CO}_{2}$. These include embodied carbon dioxide emissions of building materials, transporting the building materials, operation of the construction equipment and machinery, electricity usage at the construction site, and transportation of the construction waste on site.

The results reveal total $\mathrm{CO}_{2}$ emissions of 257,230 and 218,800 $\mathrm{kg} \mathrm{CO}_{2}$ for the ordinary reinforced concrete slab and the voided slab system, respectively. Among the five sources of $\mathrm{CO}_{2}$ emissions during the construction phase, the embodied carbon from the building materials accounts for 246,082 and $211,116 \mathrm{~kg} \mathrm{CO}_{2}$ for the ordinary reinforced concrete slab and the voided slab system, respectively. Moreover, the greatest contributor to $\mathrm{CO}_{2}$ reduction is the embodied carbon dioxide emissions of the building materials, which accounts for $34,966 \mathrm{~kg} \mathrm{CO}$. The second highest contributor is the transportation of the building materials, accounting for $3417 \mathrm{~kg} \mathrm{CO}_{2}$. On the other hand, the negative contributor is the operation of the construction equipment and machinery on site, which offset $3.2 \%$ of the total emissions reduction. The main factors that reduce the emissions of carbon dioxide from the voided slab system are the forms for casting the beams, girders, and slabs in the ordinary reinforced concrete slab. In this study, the potential reduction elements in the voided slab system compared to the ordinary reinforced concrete was investigated and it would be beneficial to lower the carbon dioxide emissions in the construction industry.

This study presents an examination of the carbon dioxide emissions in the ordinary reinforced concrete slab and the voided slab system in the construction stage. Analysis of the characteristics and comparisons of the $\mathrm{CO}_{2}$ emissions between them indicates that there are different sources and factors related to the carbon dioxide emissions. In this study, the voided slab system results in fewer emissions compared with the ordinary reinforced concrete slab, although the amount of the reduction is not significant which is indicated 830 and $820 \mathrm{~kg} \mathrm{CO}_{2}$ for the ordinary reinforced concrete slab and the voided slab system, respectively. This result illustrates that the reduction potential, which was approximately $15 \%$, exists in the construction phase in the voided slab system over the ordinary reinforced concrete slab. In this study, the economic friendliness of the voided slab over the ordinary 
reinforced concrete was corroborated empirically. Moreover, it is considered that the application of the voided slab system would contribute to the reduction of $\mathrm{CO}_{2}$ in the construction industry both domestically and internationally.

A limitation of this study is that it is focused only on one project to compare the ordinary reinforced concrete slab and the voided slab system. To corroborate the practicability and sustainability, as well as to broaden the applicability, of the voided slab system, a future study that investigates more practical cases for multiple examination of the correlation between the voided slab system and carbon dioxide emissions is required.

Author Contributions: I.P. conducted the design of two structural system of the studied building. S.N. carried out the assessment of carbon dioxide emissions of both systems.

Acknowledgments: This work was supported by the National Research Foundation of Korea (NRF) grant funded by the Korea government Ministry of Education. (No. NRF-2017R1D1A1B03033452).

Conflicts of Interest: There are no conflicts of interests between the authors.

\section{References}

1. Kim, T.H.; Chae, C.U.; Kim, G.H.; Jang, H.J. Analysis of $\mathrm{CO}_{2}$ emissions characteristics of concrete used at construction sites. Sustainability 2016, 8, 348. [CrossRef]

2. Baek, C.; Tae, S.; Kim, R.; Shin, S. Life cycle $\mathrm{CO}_{2}$ assessment by block type changes of apartment housing. Sustainability 2016, 8, 752. [CrossRef]

3. Martí, J.V.; García-Segura, T.; Yepes, V. Structural design of precast-prestressed concrete U-beam road bridges based on embodied energy. J. Clean. Prod. 2016, 120, 231-240. [CrossRef]

4. Kim, T.; Tae, S. A study on the development of an evaluation system of $\mathrm{CO}_{2}$ emission in the production of concrete. J. Korea Concr. Inst. 2010, 22, 787-796. [CrossRef]

5. Asdrubali, F.; Baldassarri, C.; Fthenakis, V. Life cycle analysis in the construction sector: Guiding the optimization of conventional Italian buildings. Energy Build. 2013, 64, 73-89. [CrossRef]

6. Hammond, G.P.; Jones, C.I. Embodied energy and carbon in construction materials. Proc. Inst. Civ. Eng.-Energy 2008, 161, 87-98. [CrossRef]

7. Hong, J.; Shen, G.Q.; Feng, Y.; Lau, W.S.-T.; Mao, C. Greenhouse gas emissions during the construction phase of a building: A case study in China. J. Clean. Prod. 2015, 103, 249-259. [CrossRef]

8. Lee, J.; Tae, S.; Kim, R. A Study on the analysis of $\mathrm{CO}_{2}$ emissions of apartment housing in the construction process. Sustainability 2018, 10, 365. [CrossRef]

9. Wang, J.; Tam, V.W.Y. Construction industry carbon dioxide emissions in Shenzhen, China. In Proceedings of the Institution of Civil Engineers-Waste and Resource Management; Thomas Telford Ltd.: London, UK, 2016; Volume 169, pp. 114-122.

10. Intergovernmental Panel on Climate Change. Global Warming of 1.5C; Intergovernmental Panel on Climate Change: Incheon, South Korea, 2018.

11. United Nations Environment Programme. Annual Report 2015; UNEP: Nairobi, Kenya, 2015.

12. Campisi, D.; Gitto, S.; Morea, D. An evaluation of energy and economic efficiency in residential buildigns sector: A multi-criteria analysis on an Italian case study. Int. J. Energy Econ. Policy 2018, 8, 185-196.

13. Yi, I.S.; Seo, K.S. Social Indicators in Korea; National Statistical Office: Seoul, Korea, 2010.

14. Cole, R.J. Energy and greenhouse gas emissions associated with the construction of alternative structural systems. Build. Environ. 1999, 34, 335-348. [CrossRef]

15. Yan, H.; Shen, Q.; Fan, L.C.; Wang, Y.; Zhang, L. Greenhouse gas emissions in building construction: A case study of One Peking in Hong Kong. Build. Environ. 2010, 45, 949-955. [CrossRef]

16. González, M.J.; Navarro, J.G. Assessment of the decrease of $\mathrm{CO}_{2}$ emissions in the construction field through the selection of materials: Practical case study of three houses of low environmental impact. Build. Environ. 2006, 41, 902-909. [CrossRef]

17. Park, J.; Tae, S.; Kim, T. Life cycle $\mathrm{CO}_{2}$ assessment of concrete by compressive strength on construction site in Korea. Renew. Sustain. Energy Rev. 2012, 16, 2940-2946. [CrossRef] 
18. Mao, C.; Shen, Q.; Shen, L.; Tang, L. Comparative study of greenhouse gas emissions between off-site prefabrication and conventional construction methods: Two case studies of residential projects. Energy Build. 2013, 66, 165-176. [CrossRef]

19. Zhang, X.; Wang, F. Assessment of embodied carbon emissions for building construction in China: Comparative case studies using alternative methods. Energy Build. 2016, 130, 330-340. [CrossRef]

20. Peng, C. Calculation of a building's life cycle carbon emissions based on Ecotect and building information modeling. J. Clean. Prod. 2016, 112, 453-465. [CrossRef]

21. Li, L.; Chen, K. Quantitative assessment of carbon dioxide emissions in construction projects: A case study in Shenzhen. J. Clean. Prod. 2017, 141, 394-408. [CrossRef]

22. Kumar, V.; Hewage, K.; Sadiq, R. Life cycle assessment of residential buildings: A case study in Canada. Int. J. Energy Environ. Eng. 2015, 9, 1017-1025.

23. You, F.; Hu, D.; Zhang, H.; Guo, Z.; Zhao, Y.; Wang, B.; Yuan, Y. Carbon emissions in the life cycle of urban building system in China-A case study of residential buildings. Ecol. Complex. 2011, 8, 201-212. [CrossRef]

24. Gan, V.J.; Chan, C.; Tse, K.; Lo, I.M.; Cheng, J.C. A comparative analysis of embodied carbon in high-rise buildings regarding different design parameters. J. Clean. Prod. 2017, 161, 663-675. [CrossRef]

25. Dong, Y.H.; Jaillon, L.C.; Chu, P.; Poon, C. Comparing carbon emissions of precast and cast-In-Situ construction methods-A case study of high-rise private building. Constr. Build. Mater. 2015, 99, 39-53. [CrossRef]

26. Guggemos, A.A.; Horvath, A. Comparison of environmental effects of steel-and concrete-framed buildings. J. Infrastruct. Syst. 2005, 11, 93-101. [CrossRef]

27. Han, Y.-S.; Kim, S.-D. A comparative study on $\mathrm{CO}_{2}$ amount of construction material in structural design. J. Archit. Inst. Korea 2005, 25, 203-206.

28. Xing, S.; Xu, Z.; Jun, G. Inventory analysis of LCA on steel-and concrete-construction office buildings. Energy Build. 2008, 40, 1188-1193. [CrossRef]

29. Kim, T.; Chae, C.; Kim, G.; Jang, H. Analysis of $\mathrm{CO}_{2}$ emission characteristics of concrete used at construction sites. Sustainability 2016, 8. [CrossRef]

30. Lee, S.; Park, W.; Lee, $\mathrm{H}$. Life cycle $\mathrm{CO}_{2}$ assessment method for concrete using $\mathrm{CO}_{2}$ balance and suggestion to decrease $\mathrm{LCCO}_{2}$ of concrete in South-Korean apartment. Energy Build. 2013, 58, 93-102. [CrossRef]

31. Cho, S.-H.; Chae, C.-U. A study on life cycle $\mathrm{CO}_{2}$ emissions of low-carbon building in South Korea. Sustainability 2016, 8, 579. [CrossRef]

32. Cho, S.H.; Chae, C.-U. The comparative study on the environmental impact assessment of construction material through the application of carbon reducing element-focused on global warming potential of concrete products. Int. J. Korea Inst. Ecol. Archit. Environ. 2015, 33, 149-156.

33. Tae, S.; Baek, C.; Shin, S. Life cycle $\mathrm{CO}_{2}$ evaluation on reinforced concrete structures with high-strength concrete. Environ. Impact Assess. Rev. 2011, 31, 253-260. [CrossRef]

34. Cho, S.; $\mathrm{Na}, \mathrm{S}$. The reduction of $\mathrm{CO}_{2}$ emissions by application of high-strength reinforcing bars to three different structural systems in South Korea. Sustainability 2017, 9, 1652.

35. Aldejohann, M.; Schnellenbach-Held, M. Investigations on the shear capacity of biaxial hollow slabs-test results and evaluation. Darmstadt Concr. 2003, 18, 532-545.

36. Cho, S.; Na, S. Evaluation of the Flexural Performance and $\mathrm{CO}_{2}$ Emissions of the Voided Slab. Adv. Mater. Sci. Eng. 2018, 2018. [CrossRef]

37. Ibrahim, I.; Elliott, K.; Abdullah, R.; Kueh, A.; Sarbini, N. Experimental study on the shear behaviour of precast concrete hollow core slabs with concrete topping. Eng. Struct. 2016, 125, 80-90. [CrossRef]

38. Lee, K.; Lee, G.; Hwang, H. Hollow Core Slab by Light Weight Assembly. Patent 1009584070000, 10 May 2010.

39. Chung, J.-H.; Jung, H.-S.; Bae, B.-I.; Choi, C.-S.; Choi, H.-K. Two-Way Flexural Behavior of Donut-Type Voided Slabs. Int. J. Concr. Struct. Mater. 2018, 12, 26. [CrossRef]

40. Lave, L.; Hendrickson, C.; Horvath, A.; Joshi, S. Economic input-output models for environment life-cycle assessment. Environ. Sci. Technol. 2002, 32, e191.

41. Miller, R.E.; Blair, P.D. Input-Output Analysis: Foundations and Extensions; Cambridge University Press: Cambridge, UK, 2009.

42. Gay, P.W.; Proops, J.L. Carbon dioxide production by the UK economy: An input-output assessment. Appl. Energy 1993, 44, 113-130. [CrossRef] 
43. Minx, J.C.; Wiedmann, T.; Wood, R.; Peters, G.; Lenzen, M.; Owen, A.; Scott, K.; Barrett, J.; Hubacek, K.; Baiocchi, G.; et al. Input-output analysis and carbon footprinting: An overview of applications. Econ. Syst. Res. 2009, 21, 187-216. [CrossRef]

44. Cabeza, L.F.; Rincón, L.; Vilarino, V.; Perez, G.; Castell, A. Life cycle assessment (LCA) and life cycle energy analysis (LCEA) of buildings and the building sector: A review. Renew. Sustain. Energy Rev. 2014, 29, $394-416$. [CrossRef]

45. International Organization for Standardization. ISO14044: Life Cycle Assessment (Requirement and Guidelines); International Organization for Standardization: Geneva, Switzerland, 2006.

46. International Organization for Standardization. ISO:21930: Environmental Declaration of Building Product; ISO: Geneva, Switzerland, 2007.

47. Gustavsson, L.; Joelsson, A.; Sathre, R. Life cycle primary energy use and carbon emission of an eight-storey wood-framed apartment building. Energy Build. 2010, 42, 230-242. [CrossRef]

48. Suzuki, M.; Oka, T. Estimation of life cycle energy consumption and $\mathrm{CO}_{2}$ emission of office buildings in Japan. Energy Build. 1998, 28, 33-41. [CrossRef]

49. American Concrete Institute. Building Code Requirements for Structural Concrete (ACI 318-05) and Commentary (ACI 318R-05); American Concrete Institute: Farmington Hills, MI, USA, 2005.

50. American Society of Civil Engineers. Minimum Design Loads and Associated Criteria for Buildings and Other Structures (7-10); American Society of Civil Engineers: Reston, VA, USA, 2010.

51. The Korea Environmental Industry \& Technology Institute (KEITI). Korea LCI DB Information Network. 2017. Available online: http://www.epd.or.kr/en/lci/lci_intro.asp (accessed on 2 April 2019).

52. Korea Ministry of Land, Infrastructure and Transport. Standard Specification for Construction; Korea Ministry of Land, Infrastructure and Transport: Sejong, Korea, 2013.

(C) 2019 by the authors. Licensee MDPI, Basel, Switzerland. This article is an open access article distributed under the terms and conditions of the Creative Commons Attribution (CC BY) license (http://creativecommons.org/licenses/by/4.0/). 